\title{
A Novel scheme of the Secure Campus Network Lei $\mathrm{AO}^{1, \mathrm{a}}$ \\ ${ }^{1}$ City institute,Dalian university of technology,Dalian,116600,China \\ aemail: 154001958@qq.com
}

Keywords: Computer network, Application services, Network system platform, Network security, Data backup

\begin{abstract}
With the extensive application of computer and the increasing popularity of the Internet, multi-data processing equipment are combined with each other, and this combination forms an increasingly huge information service platform. With the guiding principal of high reliability, high security and high scalability network system. During the design, we come up with data structure plan of internet system suits for the overall pattern of the latest informative management, according to the business mode of the informative management center and the development orientation of science and technology. The content includes five parts, plan and design of various kinds of application server, the construction of network platform, the design of the network security, data backup and operations management.
\end{abstract}

\section{Introduction}

In order to meet the needs of social development and the industry development trend of information, the school will be on campus network system has been established and network application foundation, improve the information service, build new communication platforms.

Firstly, according to the campus network of the future adjustment technology and application services of planning, put forward in line with the campus network planning and design scheme of user requirements, and the selection of the hardware platform and equipment selection of the corresponding[1]. The reconstruction scheme of network principle:

1) Campus network topology structure of the original star structure, in the new campus will be changed to ring network redundancy;

2) Data transmission rate of core layer switches support Gigabit;

3) To install a network management system software, uninterrupted surveillance and control of the import and Office Area network;

4) Outside the campus network users are required by VPN to the campus network;

5) Using DHCP dynamic IP address allocation area, use a firewall to achieve NAT private IP address and legal IP address conversion function; and separate operation and office area[2].

6) Network cabling for office area, to meet the needs of teaching and scientific research [3].

\section{The Guiding Ideology}

The construction of campus network guiding system can make the construction of campus network in the process of technology can be fully and correctly applied in the standard framework, and the techniques to maintain coordination, forms a communication platform without any contradiction. So the system is in the process of mutual connection and integration of the various technical standards reflects the most important form of campus network.

Technical specification of process can be followed by the formation of the campus network operation requirements and standards to comply with the network technology and information security technology is not only closely linked to the current requirements of the construction of campus network, but also need to satisfy the future demand of campus network maintenance and management of low cost and high efficiency.

Predictability is required to take into account not only the standard set of computer network technology and information technology application development, but also for the future 
development of pre sentence. In addition, the future demand of campus network user is variable, so the design of the campus network should be forward-looking as the guiding ideology, to ensure the future campus network unimpeded extension.

Communication platform system, guarantee the scientific establishment of application services and communication services fast, stable and safe way to achieve that is to say as the fundamental guiding ideology of the construction of campus network.

The development trend of technical specifications and standards of the advanced requirements of the process followed in the construction of campus network in should be in line with the network technology and information security technology. In the design of various characteristics of network technology and information security technology involved as well as the related domestic and international and industry standards are required to have the advanced nature.

Network equipment through the application of system platform need advanced data structure, stable reliable, redundant deployment, to ensure that the core business data and accounting data security, and the continuous operation. The authority of strict examination and approval system of internal control, business operation rights changes, reduce the system risk; improve the overall security of the system. The authentication mode has the force of law, in order to ensure the non repudiation of integrity, transaction online business data.

\section{The Proposed Campus Network}

In the application services, planning and design, mainly around the building business and accounting server, external application and maintenance server, database server, application server and application service platform are discussed. The design principle is to support the ability to handle large amounts of data, in response to many concurrent connection requests, and has good stability and scalability. On the other hand, as the core of the information management of the storage system, its security, stability, high efficiency, scalability is particularly strong, any storage system failure are likely to lead to a serious problem of the data center. In the design, the use of centralized data storage, provide a set of high performance storage system for each application system of database and network. Through the partition of storage system, the various network services to provide corresponding memory space.

In terms of the construction of online platform, we should make the online system meet the needs of application with the feature of reliability and standardization. We could separate the whole into several parts, such as, core section, service section, security section, management section, studying section, switch-in section, DMZ section and internet section. In addition, the application in accordance with its functions represents the modularity style, which can promote the management of the whole system and it's security.

In terms of data transmission system and network management, the campus network system will construct as the mode of two places and three centers. Access to the remote, asynchronous and real-time copies of core data of business system and carry out core system data's disaster recovery of two places and three centers. It will realize the application copies of core business system and the switch-in form other places data-copying center in accumulation fund apartment. In addition, it also needs a secure operative platform to install the NetEye, to release unified maintenance methods, to provide rapid and efficient operative flow, and to establish the standard managing flow.

As for the design of its security ,given that nowadays the security of the internet largely rely on firewall, intrusion detection and action checking; thus, the concerned software ane hardware must adopt the diversified ways to protect the safety of data. In conclusion, the designs about the security of internet contain configuration of firewall, detection when the virus invade the computer, a scan about a leak in the internet system, the control to the amount of the data, the testing for stooping the hacker and supervisory to web users. Therefore, the design of the campus network security design will follow the following principles:

1) in the network security design, technical requirements and pay equal attention to protection, prevention mechanism design complete, overall safety information system from the aspects of the;

2) according to the network application service requirements, in accordance with the specific 
requirements and security needs, the comprehensive test of different information system security level and the size of the risk and other content, correctly distinguish the information system in campus network security;

3) For some of the data security requirements are relatively high region, adopt various effective measures, protection of key data security and integrity;

4) Security planning and design of campus network to prevent active attacks outside and because of security threats due to staff the momentary gist;

5) Whether the safety of campus network can reach the demand depends on the weakest part of the system, should be safety protection using system planning, design and management of future maintenance matched, setting.

Test results of the network security parameters are shown in Tables 1-5. The results indicate that the proposed campus network is secure.

Table 1 The Test Parameters of Firewall Technology

\begin{tabular}{|c|c|c|}
\hline Parameter & $\begin{array}{l}\text { The Firewall of Server } \\
\text { Core Area }\end{array}$ & $\begin{array}{l}\text { The Firewall of Outreach } \\
\text { Service Export }\end{array}$ \\
\hline The Throughput Rate & $3.5 \mathrm{Gbps}$ & 1000000 \\
\hline $\begin{array}{c}\text { The Number of } \\
\text { Concurrent Connection }\end{array}$ & 2000000 & 35000 \\
\hline $\begin{array}{c}\text { The new connection } \\
\text { number }\end{array}$ & 50000 & 2Gbs \\
\hline
\end{tabular}

Table 2 The Test Parameters of Traffic Monitoring System

\begin{tabular}{|c|c|c|c|}
\hline Parameter & Flow Record & Flow Forward & $\begin{array}{c}\text { Concurrent } \\
\text { Connection }\end{array}$ \\
\hline $\begin{array}{c}\text { Traffic Monitoring } \\
\text { System }\end{array}$ & 30000 per second & 1000000 & 1000000 \\
\hline
\end{tabular}

Table 3 The Test Parameters of Intrusion Detection System

\begin{tabular}{|c|c|c|}
\hline Parameter & Flow Detection & Open the Audit Function(Y/N) \\
\hline Intrusion Detection System & 6000000000 & $\mathrm{Y}$ \\
\hline
\end{tabular}

Table 4 The Test Parameters of Internet Behavior Management System

\begin{tabular}{|c|c|c|}
\hline Parameter & $\begin{array}{c}\text { The Throughput } \\
\text { Rate }\end{array}$ & $\begin{array}{c}\text { The Number of Concurrent } \\
\text { Connection }\end{array}$ \\
\hline Behavior Management System & 7000000000 & 800000 \\
\hline
\end{tabular}

Table 5 The Test Parameters of Virus Monitoring System

\begin{tabular}{|c|c|c|}
\hline Parameter & The virus database & Open the Function(Y/N) \\
\hline \multirow{2}{*}{ Virus Monitoring System } & 1000000 & $\mathrm{Y}$ \\
\hline
\end{tabular}




\section{Conclusions}

In this design, the choice of hardware and soft ware is very important. In this paper, the choices of equipments and the implementation of technique meet following principles.

Firstly, the software and hardware should be stable and reliable. And it can fulfill demands of infrastructure project, exchange and transact of data of informational management center.

Secondly, network's hardware and software needs to provide integral and visual operative interface. It is convenient for management and network secure detection. And this platform itself must be secure and meet the integral security policies[4].

Finally, interrelated hardware and software in this design should be in accord with technical standard or industrial standard[5].

\section{References}

[1] Frederic J. Cooper, et al. Implementing Internet Security[M]. New Riders Publishing .1995

[2]EricMaiwald,Wi1liEducation,SecurityPlanning\&DisasterRecovery,2003,Posts\&Telecommunicat ions Press,PP.86-94

[3]WANG Yue. Influence maximization with limit cost in social network[J]. Science China(Information Sciences,2013,(07)67-70.

[4] ZHAO Jing. Complex networks theory for analyzing metabolic networks[J]. Chinese Science Bulletin,2006,13(4)58-63.

[5] W.Richard Steven.TCP_IP detailed volume 1: protocol [M]. Beijing: Tsinghua University press, 1998 